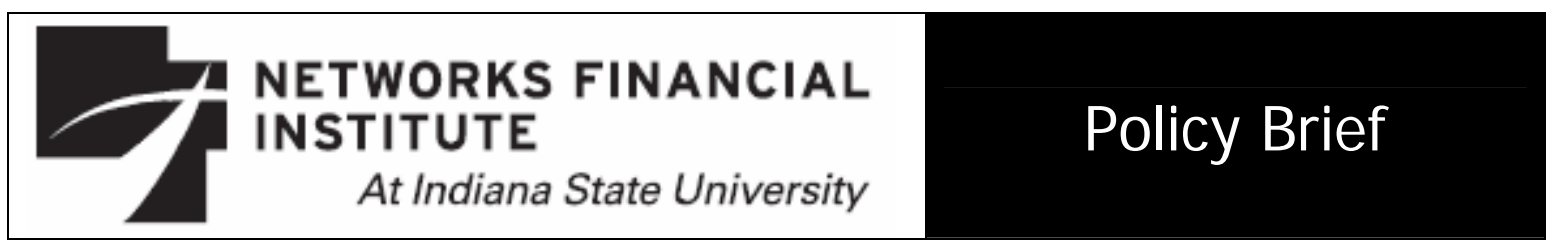

2006-PB-13

July 2006

\title{
Capital Regulation and Loan Monitoring in a Diverse Banking System
}

\section{David VanHoose}

Abstract: Building on the literature emphasizing banks' monitoring functions, recent contributions to the literature examining the effects of capital regulation have focused attention on the influences of capital requirements on bank incentives to monitor loans for moral hazard risks. Empirical evidence suggests that this is a potentially important issue to contemplate when judging the usefulness of capital regulation as a means of reducing banking risks. This evidence also suggests, however, that various heterogeneities, which are commonly ignored in studies of the effects of capital regulation on bank monitoring and overall asset risk, are an important feature of realworld banking markets. In theory, bank heterogeneities can affect the manner in which the entire banking system responds to external shocks, such as the imposition of capital requirements. A few recent studies cast light on how diversity relating to loanmonitoring activities of banks affects their decision making and thereby influences market outcomes, which in turn feed back to alter individual bank choices regarding whether or how much to monitor their loans. In this way, the policy implications of capital regulation differ from those forthcoming from standard studies of banking systems populated by identical, representative banks.

About the Author: David VanHoose is a Senior Fellow at Networks Financial Institute. VanHoose earned his Ph.D. at the University of North Carolina at Chapel Hill and is currently the Herman W. Lay Professor of Private Enterprise at the Hankamer School of Business at Baylor University. He has published articles in such professional journals as the Quarterly J ournal of Economics, the International Economic Review, the Southern Economic Journal, the J ournal of Money, Credit, and Banking, Economic Inquiry, and the Scandinavian J ournal of Economics.

Keywords: bank loan monitoring, risk-based capital regulation

The views expressed are those of the individual author and do not necessarily reflect official positions of Networks Financial Institute. Please address questions regarding content to David VanHoose at

David_VanHoose@baylor.edu. Any errors or omissions are the responsibility of the author.

NFI working papers and other publications are available on NFI's website

(www.networksfinancialinstitute.org). Click "Research" and then "Publications/Papers." 


\section{Capital Regulation and Loan Monitoring in a Diverse Banking System*}

\section{David VanHoose}

\section{Introduction}

A commonly articulated objective of bank capital regulation is to induce banks to hold a capital cushion judged to be adequate for protecting depositors and deposit insurers from costs that could arise in the event of individual or system-wide bank failures. A relatively large capital cushion could speedily dissolve, however, if banks react to capital requirements by selecting riskier asset portfolios or by failing to limit the wide ranges of risks that they face. For this reason, a proper assessment of the effects of bank capital regulation must take into account whether such regulation induces banks to make choices that reduce their risk exposures.

Over the past two decades, based largely on work by Diamond (1984, 1991, 1996), the banking literature has focused much attention on one characteristic that makes banks “special” (see Kwan, 2001). This characteristic is banks’ role in monitoring loans and thereby attempting to contain the highly idiosyncratic risks associated with these financial assets. Banks performing this task more efficiently using existing resources presumably make higher-quality loans and thereby reduce overall risks of loss and failure probabilities. Recently, Diamond and Rajan (2000, 2001, 2006) have built on these ideas to propose theories of banking markets, bank capital choices, and the role of banks as providers of assets that function as money.

During the same period, increasing attention has been given to trying to understand how banks respond to actual and proposed forms of capital regulation. This literature (see reviews by Santos, 2001, and VanHoose, 2006) has contemplated the implications of

\footnotetext{
* I am grateful for comments on earlier drafts by Kenneth Kopecky and Jack Tatom.
} 
capital requirements for bank decision-making from various perspectives. Early studies exploring the responses of banks to capital regulation focused on models of an individual bank functioning as a competitive, mean-variance portfolio manager facing capitalconstrained asset portfolios. Later work broadened the scope of analysis to encompass incentive effects simultaneously operating on both sides of a bank's balance sheet. This naturally led to considerations of deposits as potentially unstable demandable debt. Eventually, theories of bank capital regulation emerged that emphasized inherent informational asymmetries, with banks offering screening services to address adverse selection problems and/or engaging in monitoring to deal with moral hazard problems.

The last of these extensions has considered whether capital regulation contributes to more extensive loan monitoring and a higher-quality asset portfolio. Among the few studies that have addressed the question, most (see Besanko and Kanatas, 1996; Campbell et al., 1992; Decamps et al., 2004; and Santos, 1999) have followed much of the rest of the literature in an important respect. They have utilized representative-bank models, in which reactions of a model bank to capital regulation are assumed to apply to all other banks. Implicitly, representative-bank models assume that the banking system is composed of behaviorally identical institutions, all of which respond in the same way to capital requirements.

There are good reasons, however, to question the reasonableness of disregarding bank heterogeneities. The U.S. banking system encompasses institutions that are highly diverse along such dimensions as size, portfolio mix, operational structure, and technological sophistication. In a heterogeneous banking system, some banks will face incentives that induce them to opt for more or less loan monitoring than other banks.

Indeed, a key rationale for bank regulation is to rein in activities of banks that are more predisposed to expose themselves, their depositors, and the deposit insurance system to greater risks of asset erosion than other banks choose. This is why bank regulators utilize elaborate methods of classifying individual banks based on idiosyncrasies in 
operational management and asset-liability mix. Presumably, banking diversity also helps to explain why it is that only a fraction of the U.S. banking system is constrained by capital requirements at any given point in time.

Naturally, accounting for the interaction between bank-level and system-wide effects of capital regulation in an environment with heterogeneous banks is a challenging undertaking. This undoubtedly helps to explain why only a few studies have attempted to examine the likely implications of capital regulation in such a setting. This paper discusses the handful of recent efforts to examine the effects of capital regulation on the extent of loan monitoring within the banking system. Its focus is placed on what "new" implications emerge once a diversity of banks is considered in analyses of bank capital regulation. This paper explains why bank heterogeneities can prove important in assessing the effects of capital requirements, and it discusses recent approaches to analyzing capital regulation in a system composed of diverse banks.

The next section reviews existing evidence on the empirical relevance of theories assigning a special role to banks as originators and monitors of loans and that emphasize differences across banks in fulfilling that role. Section 3 explains why representative-bank models can fail to capture important feedback effects between individual bank choices and aggregate loan-market equilibrium with and without capital requirements. Section 4 then discusses recent studies by Kopecky and VanHoose (2006a,b,c) that seek to better understand how capital regulation can alter the system-wide degree of bank monitoring. The final section concludes by summarizing the key policy implications for the implementation of capital regulation within a diverse banking system and a discussion of issues that should be addressed in future research on this topic.

\section{Evidence on the Bank Screening and Monitoring Activities}

Is there evidence that banks do provide special monitoring services, the provision of which might be affected by capital regulation? Most evidence is indirectly derived 
from loan announcement effects, bond yields and rates on syndicated loans, and loan sales. Direct evidence relating to bank loan monitoring has recently emerged only in a single study, Mester et al. (2005), which is discussed later in this section.

\subsection{Evidence from Bank Loan Announcement Effects}

Initial evidence that banks perform special functions is contained in James (1987), who analyzes more than 200 firms’ financing announcements-including announcements of both private and public debt placements and loans from banks_-between 1974 and 1983. He finds that announcements of debt issues tended to generate abnormal negative stock returns for the borrower. In contrast, announcements of bank loans generate positive abnormal returns. This, James concludes, is evidence that valuable private information is encompassed with the lender-borrower relationship, which suggests that banks do indeed provide screening and monitoring functions with perceived value to the recipients.

Building on James (1987), Billett et al. (1995) construct and examine a sample of nearly 1,500 corporate loan announcements between 1980 and 1989 and examine whether the identity of the lender affected the market response of the borrower's stock returns. They find that firms borrowing from banks with higher credit ratings experienced higher abnormal returns, with each one-unit increase in the lender's credit rating boosting the borrower's return by 20 basis points during the day following a loan announcement. Billett et al. propose that a higher positive response of a borrower's stock returns to announcement of a loan by a lender with a superior credit rating likely reflects loanannouncement signaling effects. They note, for instance, that a stronger credit rating for a lender could proxy for that bank’s monitoring effectiveness, which in turn influences the perceived likelihood that it will repay depositors and other creditors. To the extent that this signaling effect lies behind the higher positive response of a borrower's stock returns, Billet et al.'s results suggest that markets perceive that banks have heterogeneous 
monitoring capabilities that, in turn, provide an indication of the quality of their customers’ loans.

\subsection{Evidence from Firm Investment and Bond Yields}

As an alternative way of gauging how the use of bank lending services affects borrowers’ performances, Hoshi et al. (1991) examine panel data on Japanese manufacturing firms. Hoshi et al. find that firms that are members of industrial groups, or keiretsu, receiving financing from large city banks are able to undertake more investment than non-members because of relaxed liquidity constraints associated with closer keiretsu ties with banks. Although they acknowledge that various services provided by keiretsu contribute to this outcome, they suggest that a key factor accounting for this outcome might be the loan-monitoring activity of the keiretsu banks.

Datta et al. (1999) study yield spreads on public bond offerings of firms that are bank borrowers. They find that the first public straight bond offers of firms with longerstanding borrowing relationships with banks have yield spreads about 68 basis points lower than firms without such relationships. This finding, the authors suggest, supports Diamond's (1991) thesis that market participants view bank monitoring functions as value-enhancing for borrowers.

\subsection{Evidence from Syndicated Loans and Loan Sales}

In addition, Casolaro et al. examine more than 14,000 syndicated loan facilities organized by a single lending institution between 1990 and 2001. They find that for syndicated loan facilities created for all but the largest, most reputable borrowers that presumably have most market transparency, there is a negative relationship between the loan rate granted by lending syndicates and the share of credit risk retained by the original facility organizer. Although this relationship might also be explained by a rising marginal cost associated with increases in syndicate participation, Casolaro et al. interpret this result 
to be consistent with a certification effect. They suggest that greater retention of credit risk by a syndicated loan organizer increases that lender's incentive to maintain its level of monitoring, thereby reducing the interest rate at which the syndicate as a whole is willing to extend credit to the borrower.

Gande et al. (1997) likewise find evidence of a certification effect that has operated when banks' section 20 subsidiaries underwrite firm debt securities. Yields on such securities issued between 1993 and 1995, they find, tended to be lower than those underwritten by traditional investment banks, indicating that markets assigned value to the monitoring functions performed by banks in their dealings with firms in lender-borrower relationships.

Gorton and Pennacchi (1995) study the characteristics of a sample of major U.S. banks that engaged in loan sales in 1987 and 1988 and examine the features of the 872 loans these banks sold. They find that the banks typically retained a smaller share of the higher-risk loans that presumably necessitate greater monitoring, which their theoretical analysis indicates reduces the loan default premium that loan buyers require in order to purchase the loans. To induce borrowers to purchase higher-risk loans at prices incorporating lower default premia, banks retained larger portions of these higher-risk and presumably more “special” loans for which greater monitoring effort was required.

Dahiya et al. (2003) conduct an event study focused on the relationship between secondary-market bank loan sales that were announced between 1995 and 1998 and the subsequent performances of borrowers whose loans were sold. They find evidence that loan sales are associated with subsequent defaults and consequent lower returns on the loans, which also supports the existence of a certification effect. In addition, Dahiya et al. provide evidence both that the sale of loans foreshadowed ultimate failure by a significant portion of the affected borrowers and that such failures could not have been readily predicted using public information. These conclusions, Dahiya et al. suggest, offer 
support for the hypothesis that banks are able to detect loan risks not readily observable to other investors.

Dahiya et al. also investigate the characteristics of banks that engaged in loan sales during their sample period. They find that banks that sold loans during their sample period were distributed relatively evenly among other non-selling banks based on income-asset ratios and that selling banks' returns were unaffected by the loan sales. Nevertheless, most banks that sold loans were relatively low-capital banks that rated among the 50 percent of banks with bad loan reserves in relation to total assets. By and large, the loan sales generated increases in these banks’ capital ratios, suggesting that for these banks, the sales entailed efforts to shrink loan portfolios and reduce asset risk.

\subsection{Direct Evidence of Bank Monitoring Activities}

The studies discussed above provide only indirect evidence regarding the hypothesis that banks uniquely provide services as monitors that improve the quality and, hence, the market value of loans. The best sources of data regarding resources that banks apply to the task of monitoring and the nature of bank monitoring operations are banks themselves. Such data are typically proprietary, however. Economists’ lack of access to such data has tended to limit the capability to directly evaluate the scope of banks’ monitoring activities.

One exception is a recent study by Mester et al. (2005), which examines data from a single Canadian bank. Mester et al. find that monitoring of transactions deposits held with the lender by a borrower — conducted via item-by-item reconciliations of transactions - enables a bank to verify the reliability of the borrower's statements about flows of accounts receivables and inventories.

The analysis of Mester et al. indicates that that the provision of transactions deposits to borrowers permits banks to access information about borrowers' behavior that is not available to other potential lenders. Finance companies or other lenders, including 
banks, which lack direct depository relationships with borrowers must expend additional resources to attempt to partially compensate for absence of such information. Furthermore, even banks with access to depository transactions data must expend resources to utilize it for purposes of monitoring the activities of borrowers.

\section{Costly Monitoring, Diversity, and Analysis of Capital Regulation}

The empirical evidence reviewed above suggests that banks do provide specialized monitoring services that have market value. The evidence also indicates that monitoring the activities of borrowers requires lenders to utilize costly resources. Finally, the empirical evidence suggests the possibility that differences may exist in banks' monitoring effectiveness.

\subsection{The Limitations of Representative-Bank Monitoring Models}

The finding that bank loans are special and that the monitoring services they provide have value is consistent with Diamond's $(1984,1991)$ proposition that bank monitoring reduces moral hazard risks that would otherwise reduce loan payoffs. The finding that monitoring requires the expenditure of real resources is consistent with Diamond's work and much of the following literature on bank monitoring.

The potential for banks to exhibit diverse stances regarding loan monitoring is not considered in Diamond's work or in the bulk of the literature that has followed, however. Most analyses in the mold of Diamond's work, including those that explore the implications of capital regulation for the extent to which banks monitor their loans, assume that monitoring costs are equal across representative banks and that these costs are fixed at the same level irrespective of loan volume. Furthermore, virtually all of these studies assume that all financial institutions either monitor with identical effectiveness or do not monitor at all. It follows that in the context of a stark, Diamond-type framework, one possible outcome of bank capital regulation is that it could induce all institutions to 
monitor if they were not already doing so when unregulated. A second possibility is that capital requirements might give all institutions an incentive to halt their monitoring activities if they had already been monitoring when unregulated. A third possibility is that capital requirements could have no effect whatsoever on the entire banking system's monitoring stance.

Diversities in monitoring effectiveness across banks suggested by the empirical evidence cast doubt on the relevance of the representative-bank assumption and the implied set of potential outcomes for the banking system. Instead, the evidence indicates that in a realistic financial environment, bank managers possess diverse monitoring skills. As a consequence, monitoring costs are likely to differ across banks. A representativebank framework is likely to be an inappropriate approach for analyzing the effects of capital regulation on the behavior of individual banks and, therefore, of the banking system as a whole. 


\subsection{How Bank Diversity Can Influence the Effects of Capital Regulation}

For the sake of simplicity, suppose that borrowers are homogeneous, which rules out complications relating to banks choosing alternative efforts to sort among borrowers. In addition, suppose that adverse selection risks are not an issue. Furthermore, suppose that borrowers incur minimal costs as a result of banks' monitoring efforts. In this setting, suppose that monitoring costs experienced by banks are not fixed but instead vary with the size of a bank's loans. A bank contemplating whether or how much to monitor borrowers will weigh its own marginal monitoring cost against the marginal benefit, which, to the extent that monitoring reduces exposure to risks, is a higher expected net return on loans. Because marginal monitoring costs are likely to vary across banks, decisions about whether or how much to engage in monitoring activities also can potentially differ from bank to bank. Thus, in contrast to the prediction of representative-bank models of the bank monitoring choice, all banks will not necessarily make the same monitoring choice, either with or without capital regulation. At any given time, for instance, one portion of the banking system may choose to engage in monitoring of borrowers, while another portion of the banking system may choose not to do so.

In a banking system in which one portion of institutions monitors while the remaining portion does not, market outcomes arguably should be influenced by the size of the share of banks that chooses to expend resources to monitor loans. Banks that employ resources to monitor borrowers incur costs that banks that do not monitor (or that engage in lower levels of monitoring) do not incur. In addition, banks that engage in monitoring reap benefits in the form of higher expected returns that are not obtained by nonmonitoring banks.

Even if monitoring banks and non-monitoring banks (or banks that monitor less intensively) are identical in other respects, the differing costs and benefits associated with their monitoring decisions typically will induce them to choose to lend different amounts at any given market loan rate. For instance, for a given loan rate and given asset scale and 
mix, a bank that chooses to monitor it loans but faces relatively high marginal monitoring costs will tend to extend a smaller quantity of loans. Thus, loan supply functions will vary across individual banks, depending on their monitoring choice and, if they choose to monitor, the marginal costs that banks incur when they do so.

Of course, the total supply of loans is the sum of all banks' loan supplies. Because loan supply decisions vary depending on whether or how intensively banks monitor their loans, it follows that aggregate supply must vary with the shares of banks that do and do not monitor their loans (or that monitor at relatively lower levels). This reasoning implies

that in an overall market equilibrium, in which banks jointly make monitoring and lending decisions, the market quantity of loans and the market loan rate must depend on the shares of banks that monitor and of banks that do not monitor (or that monitor less intensively).

Furthermore, it follows logically that variations in the public's loan demand or in other factors that affect loan supply—such as capital requirements—-will affect the market loan rate. Such an induced change in the loan rate, in turn, will feed back to influence monitoring incentives, thereby affecting the share of banks that engage in such activities (or that do so at a relatively high level). Thus, in a diverse banking system, there is bound to be an interplay between the effects that capital regulation have on the choices of individual banks and the effects that these decisions have on market outcomes.

By their nature, representative-agent models present difficulties for researchers seeking to capture this interplay between bank- and market-level outcomes. A model that takes into consideration heterogeneous monitoring costs or benefits is more likely to more reveal full effects of capital regulation on monitoring choices, aggregate lending, and the market loan rate in a diverse banking system.

\section{Capital Regulation and Loan Monitoring in a Diverse Banking System}

Only a very few studies have examined how bank heterogeneities matter for a bank's capital decision without or with capital requirements. Exceptions, reviewed in 
VanHoose (2006), include Morrison and White (2005), in which bank regulators must screen applicants with differing loan-monitoring capabilities, Almazon (2002), in which heterogeneous banks balance capital versus monitoring expertise, and Boot and Marinc (2006), which diverse banks make costly investments in technologies that determine the benefits from monitoring.

To date, the only studies of banking systems made up of heterogeneous institutions both without and with binding capital requirements have been those by Kopecky and VanHoose (2006a,b,c). These studies examine short- and long-run settings in which a portion of banks monitor their loans for moral hazard risks and a portion do not. The aim of these studies is to evaluate key elements of bank behavior both before a capitalregulation regime is implemented and after capital requirements have been imposed.

\subsection{Short-Run Effects of Capital Regulation with Heterogeneous Monitoring Costs}

In the short-run environment considered by Kopecky and VanHoose (2006c), the book value of equity is assumed to be predetermined for all banks. Furthermore, they assume that costs incurred by monitored borrowers are insignificant. Kopecky and VanHoose also assume that banks that choose to monitor thereby eliminate loan losses generated by moral hazard risks and obtain a higher loan returns. To achieve this outcome, an individual bank must incur a monitoring cost that rises with greater lending. Naturally, a bank does not incur this cost if it chooses not to monitor, in which case the bank is fully exposed to moral hazard risks that reduce its effective loan return.

Kopecky and VanHoose assume that banks are identical in every single respect except one: They incur differing monitoring costs that are presumed to reflect diverse management skills. Of course, banks that choose not to monitor their loans do not incur monitoring costs, so profit-maximizing non-monitoring banks opt for identical balancesheet configurations. At any given set of market interest rates on deposits, securities, and 
loans, they issue the same amounts of deposits and opt to hold the same asset portfolio consisting of homogeneous securities and loans exposed to the same moral hazard risks.

The monitoring benefit-cost trade-off faced by an individual unregulated bank depends on its portfolio choices as well as on the bank's own marginal monitoring cost and the loan-return benefit from monitoring for moral hazard risks. All banks that choose to monitor face different benefit-cost trade-offs, because their marginal monitoring costs differ. Consequently, at given loan, security, and deposit rates that influence the monitoring benefit-cost trade-off faced by unregulated banks, each profit-maximizing monitoring bank desires to lend a different amount than other banks that monitor. Furthermore, some monitoring banks lend more than a non-monitoring bank, while other monitoring banks desire to lend less than a non-monitoring bank.

Without or with capital regulation, two conditions must be satisfied in a short-run equilibrium in the loan market:

(1) The quantity of loans demanded must equal the aggregate quantity of loans supplied by all banks at a single market loan rate. Thus, Kopecky and VanHoose, consider only a pooling equilibrium, which is more likely to exist for relatively low moral hazard risks and hence relatively small monitoring benefits. Otherwise, a separating equilibrium can arise, leading to separate markets, with one market including monitoring banks and the other populated only by non-monitoring banks.

(2) Banks that opt to monitor at the market loan rate must earn profits at least as high as those earned by non-monitoring banks. Otherwise, at the margin these banks would be induced to opt to alter their monitoring stance and choose to be among the nonmonitoring banks

In the absence of capital requirements, these two conditions together yield the market loan rate and the equilibrium share of institutions in the banking system with 
monitoring costs sufficiently low to yield profits at or above the profits earned by nonmonitoring banks. One natural implication of the model is that increased bank exposures to moral hazard risks boost the benefit from monitoring, which induces an increase in the share of institutions in the banking system that opt to monitor their loans. Another sensible implication is that a system-wide increase in marginal monitoring costs generates a decrease in the portion of banks that monitor.

Without capital regulation, the identical non-monitoring banks make the same choices. Each monitoring bank that faces its own unique cost of monitoring, however, extends different quantities of loans and hence selects a different capital-to-loan ratio. Thus, when a uniform risk-based (equity-to-loan) capital requirement ratio is imposed on this model banking system, not all banks are necessarily constrained. A portion of monitoring banks choose to lend more than non-monitoring banks, which in turn opt to extend more loans than the remaining monitoring banks. An interesting feature of the model, however, is that the first banks to be constrained by a capital requirement are monitoring banks that lend more than all the identical non-monitoring banks. These monitoring banks are the banks with the lowest marginal costs of monitoring, presumably reflecting greater monitoring efficiency. This result points to one possible outcome of capital regulation: Some of the banks more likely to be constrained by a capital requirement could be among the most efficient loan monitors and would otherwise choose to extend more loans in relation to their equity.

There are a host of possible responses to capital regulation, depending on the size of the capital requirement ratio. Kopecky and VanHoose (2006c) consider model calibrated simulations - "calibrated" in the sense that, where feasible, values of parameters such as interest rates and cost parameters are selected based on data or empirical estimatesinvolving two specific cases. In one situation, which comes closest to replicating a representative-bank outcome, the required capital ratio is sufficiently high that the entire banking system is capital-constrained. Because banks' identical equity levels are fixed in 
the short run, they must adjust by reducing their loans to the same, constrained level. One consequence is that aggregate loan supply decreases, so the market loan rate increases. Another consequence is that with each bank's lending constrained to a fixed level, the interdependence between the bank's portfolio and monitoring decisions is severed. The only bank-related factors that matter in the new, constrained monitoring trade-off are the magnitude of each bank's monitoring cost and the size of the moral hazard risk that can be eliminated by monitoring. Along this constrained trade-off, only banks with particularly low marginal monitoring costs can justify continuing to monitor their lending in the presence of all-binding capital requirements. Thus, the overall extent of loan monitoring in the banking system declines. Even though total bank lending is lower when all banks are capital-constrained, thereby reducing the banking system's vulnerability to moral hazard risks, the degree of monitoring of these loans declines, thereby increasing this aggregate risk. On net, imposing capital requirements that constrain the entire banking system has an ambiguous effect on the overall exposure of the banking system to moral hazard risks.

Once the entire banking system is bound by capital requirements, an additional tightening of the risk-based requirement ratio generates a further contraction of total lending. At the same time, there is a moderate increase in the share of banks that monitor loans due to the reduced marginal monitoring cost that accompanies the additional loan reduction. Hence, tougher capital requirements in an already all-bound banking system unambiguously reduce the banking system’s overall exposure to moral hazard risks.

The other case considered by Kopecky and VanHoose (2006c) is one in which a specific, relatively small portion of banks — namely, those monitoring banks that lend more than non-monitoring banks - is constrained by capital requirements. As a consequence, aggregate loan supply decreases somewhat, and there is a miniscule rise in the market loan rate. The previously monitoring banks that are now bound by capital regulation to the same lending level as non-monitoring banks then re-evaluate whether or 
not to monitor by weighing their monitoring costs against the size of the moral hazard risk that can be eliminated by monitoring. Along this constrained trade-off, only banks with particularly low marginal monitoring costs can justify continuing to monitor their lending in the presence of all-binding capital requirements, so a portion of the previously monitoring banks chooses to halt monitoring activities. There is a decline in total lending but a reduced fraction of monitoring banks, so the banking system's aggregate exposure to moral hazard risks may rise or fall. While total lending subject to moral hazard risk decreases, the fraction of unmonitored loans also rises. The overall change in exposure to moral hazard risk depends, on the one hand, on the relative impacts of the slightly reduced aggregate loan quantity on the one hand and, on the other hand, on the slightly increased fraction of unmonitored loans.

Analogously to the all-constrained case, once capital regulation is in place, additional increases in the required capital ratio generate an increase in aggregate loan quality. All banks reduce their lending further, which reduces their exposure to moral hazard risks. In addition, an even larger share of banks is induced to monitor their loans for such risks.

\subsection{Long-Run Effects of Capital Regulation with Heterogeneous Monitoring Costs}

In the long run, a bank can adjust equity to a level that maximizes the institution's market value. To examine long-run effects of bank capital regulation, Kopecky and VanHoose (2006b) consider a setting in which groups of banks with differing monitoring costs are initially established and financed by equity in initial public offerings (IPOs). Banks then combine this equity with deposits, which for the sake of simplicity are assumed equal to a fixed amount, and hold a portfolio of assets including loans that the banks either do or do not monitor for moral hazard risks. Competition among potential equity owners in the IPOs-which must generate rates of return sufficient to match the market overall return on alternative uses of equity funds-drives equity cash investments 
in the banks to equality with the market value of equity ownership, which equals the discounted value of the stream of profit that banks generate. Thus, in the long-run equilibrium considered in this model, the value of Tobin's Q, the ratio of the market value of equity to the book value of equity, is always equal to unity.

Banks choose equity levels that maximize their market values depending on their mode of operation-monitoring versus non-monitoring. Each group of banks compares the market value of equity with and without monitoring and simultaneously determines both the value-maximizing amount of equity to issue and whether or not to monitor. The model yields three potential outcomes: (1) both groups monitor; (2) the group with lower monitoring costs monitors and the other group does not, or (3) both groups of banks choose not to monitor.

Kopecky and VanHoose (2006b) conduct separate simulations of the model yielding all three types of outcomes. In each model simulation, they initially assume that the banking system is unregulated and, for a selected range of market loan rates, calculate value-maximizing equity levels implied by the model with and without monitoring. Three representative simulations reveal the main implications of the analysis. In the first simulation, there are relatively low marginal monitoring costs for both groups of banks and a comparatively large moral hazard risk, and in this situation both groups will maximize the value of equity by monitoring. In the second simulation, one group faces a higher marginal monitoring cost, and the moral hazard risk is somewhat lower, with the result that one group chooses to monitor while the other group does not. In the third simulation, both groups face relatively high marginal monitoring costs and comparatively small moral hazard risk, which yields a no-monitoring equilibrium for the entire banking system. In all cases, higher market loan rates push up lending returns and thereby induce increases in the desired amount of funds invested in the IPOs and in the equilibrium market value of banks. 
Kopecky and VanHoose (2000b) then redo the simulations under the assumption that banks face a required minimum equity-to-loan ratio of 4 percent. Naturally, one issue of interest is whether capital regulation would induce a switch in monitoring status by the groups of banks that had not monitored when unconstrained in the second and third simulations. In fact, non-monitoring groups fail to change their monitoring status in any of the simulations considered. For a range of loan rates in the second simulation, a group of banks that had monitored when unregulated opts to stop monitoring under capital requirements. Thus, the model does not indicate that capital regulation necessarily tends to induce more widespread bank monitoring for moral hazard risks.

Another issue of interest is whether capital regulation induces a long-run inflow or outflow of equity into or from the banking system — that is, whether, the long-run market value of the banking system increases or decreases due to capital regulation. In all simulations, the long-run market value of equity for both groups of banks rises when banks face capital requirements. For the same range of loan rates considered in the simulations for an unregulated banking system, banks respond to capital regulation by increasing equity and lending, which in the long run feeds back to boost their market values.

Finally, the model can be used to compare simulated equity shares of monitoring banks before and after capital regulation. The most interesting of these simulations is the second case in which lower-monitoring-cost banks engage in monitoring but the other group of banks does not. The equity shares going to monitoring banks in an unregulated banking system vary across the range of loan rates considered in the simulation, rising at first with higher loan rates and then falling off somewhat. In contrast, for banks that face capital requirements the share of total bank equity going to monitoring banks does not vary with the loan rate, because all banks are constrained to lending consistent with the regulatory capital ratio irrespective of the return on loans. Furthermore, the share of total equity at monitoring banks decreases under capital regulation. Because total equity and 
loans increase in the long run under capital requirements at both monitoring and nonmonitoring banks, so do the marginal costs of monitoring. Other things being equal, therefore, the market value of equity at monitoring banks is somewhat lower than at nonmonitoring banks.

Of course, because the entire banking system experiences a long-run absolute inflow of equity, under capital regulation the levels of equity are higher at both monitoring and non-monitoring banks. Nevertheless, this before-and-after equity comparison implies that more of the inflow of new equity into the banking system occuring when capital requirements are imposed will find its way to non-monitoring banks.

\subsection{Long-Run Effects of Capital Regulation with Different Monitoring Costs and Benefits}

A key simplifying feature of the Kopecky and VanHoose (2006b,c) analyses is the assumption that monitoring enables banks, with certainty, to completely eliminate default risks. Kopecky and VanHoose (2006a) continue to consider an environment in which banks face costs of monitoring, but they more realistically assume that banks face a known random risk distribution. In addition, they assume that the act of monitoring reduces the upper and lower limits of this distribution. In light of the resulting analytical complexities, Kopecky and VanHoose adopt a representative-bank assumption. Nevertheless, they consider the effects of varying the model banking system's costs and benefits of monitoring. In this way, the analysis potentially can cast light on the diverse effects of capital regulation across banking systems with different monitoring costs and benefits or within the same banking system as monitoring costs and benefits vary over time.

In this revised environment, banks making long-run decisions about whether to act as monitors or nonmonitors must base their choices on the expected market values resulting from those choices, given the distribution of risks that they face as lenders and their common endowment of monitoring costs and benefits. Even though Kopecky and 
VanHoose (2006a) simplify by assuming that this distribution is uniform, the model does not yield closed-form analytical solutions, so they again evaluate the model via calibrated simulations. To conduct these simulations, they consider both relatively "high-risk distributions,” or distributions with relatively high upper and lower limits of default risks, and relatively "low-risk distributions," or distributions with relatively low upper and lower limits. In addition, they specify endowments of both monitoring costs and monitoring benefits, in which the latter is a fixed amount by which monitoring shifts down both the upper and lower limits of a given risk distribution.

To evaluate the model's predictions regarding the effects of bank capital regulation on monitoring choices, Kopecky and VanHoose (2006a) compare two configurations of default-risk distributions and monitoring costs and benefits that might relate to the U.S. banking system during alternative historical periods. One is intended to correspond to a period with relatively low upper and lower limits for the range of loan default risk and a relatively high ratio of monitoring costs of monitoring benefits, similar to the 1950s and 1960s. Another is aimed to represent a period with higher loan default risk and a lower monitoring cost-benefit ratio, similar to the 1980s and 1990s. In both types of simulations, Kopecky and VanHoose consider initial situations in which the model banks would, if unregulated, choose not to monitor their loans. Then they evaluate whether binding riskbased capital requirements would induce banks to monitor their loans.

The simulations for these two configurations of the model produce contrasting conclusions about the effects of binding capital requirements. In a low-risk banking system in which access to relatively primitive monitoring technology yields a relatively high ratio of monitoring costs to monitoring benefits, implementing risk-based capital requirements has no effect on banks' monitoring decisions. Furthermore, the simulations indicate that under circumstances in which such a banking system was initially monitoring prior to capital regulation, tightening the requirements could induce banks to halt their monitoring activities. In a higher-risk banking system in which access to sophisticated 
monitoring capabilities generates a smaller ratio of monitoring costs to benefits, imposing sufficiently restrictive risk-based capital regulation ultimately induces banks to monitor their loans.

The reason that the effects of capital regulation differ for the alternative configurations relates to the fact that the imposition of binding risk-based capital requirements affects the marginal return to making loans safer by monitoring. This marginal return depends directly on the extent to which monitoring reduces the upper and lower limits of the loan default distribution. In the higher-risk setting with a small ratio of monitoring costs to benefits, this marginal return is much higher than the alternative configuration. Thus, risk-based capital requirements are more likely to induce nonmonitoring banks to become monitors in a high-risk environment in which the ratio of monitoring costs to monitoring benefits is low.

A key policy implication of this work is that risk-based capital regulation is less likely to induce non-monitoring banks to switch to a monitoring stance in banking systems in which default risks are relatively low and in which monitoring technology is relatively inefficient and ineffective. These conditions were more likely to be satisfied in the past U.S. banking system or in banking systems located in less developed nations. Hence, riskbased capital regulation is less likely to induce banks to monitor their loans in such settings. In contrast, in modern, U.S.-style banking systems facing potentially greater risks but possessing more efficient and more effective monitoring technologies, risk-based capital regulation is more likely to induce non-monitoring banks to switch to a monitoring stance.

\subsection{Short- and Long-Run Implications of Capital Regulation: A Summary}

Taken together, what do the Kopecky-VanHoose studies of capital regulation in diverse banking systems tell us about the short- and long-run effects of capital requirements? First, they imply that in the short run, when banks cannot adjust their 
equity, capital requirements that bind either all banks or, more realistically a subset of banks, may either improve or worsen the aggregate riskiness of loans extended by the banking system. Imposing fully or partially binding requirements reduces the capability of banks to lend, which reduces their aggregate exposure to moral hazard risks.

Nevertheless, the share of banks that engages in costly monitoring of loans for these risks tends to decline. The new short-run effect on aggregate loan quality is ambiguous. Only after capital requirements are in place do tougher capital requirements tend to improve loan quality for the banking system as a whole, but this is mainly because tighter capital regulation induces contractions in total lending. Furthermore, among the first banks bound by capital requirements are likely to be the most efficient loan monitors that naturally extend more loans relative to equity when unregulated. Thus, capital regulation has shortrun distributional efficiency effects, in which lower-cost monitors effectively can be “punished” for their greater efficiency.

In the long run, when banks are able to adjust their equity to the point at which the market and book valuations of equity are identical, there is a tendency for more equity to flow into a banking system that is subject to capital requirements. Thus, one predicted long-run effect of capital regulation is an increase in the absolute capital "cushion” for the banking system as a whole. Total lending increases as well, however, implying that the relative size of this cushion will remain no greater than the required capital ratio.

Furthermore, the analysis predicts that new equity will not flow evenly into a capital-regulated banking system. Because equity owners can anticipate a higher market value of equity from banks that choose not to monitor, these banks will tend to grab a larger share of the equity inflow. All banks are predicted to receive additional equity, but a greater portion of this equity is likely to flow to banks that choose not to monitor their loans for moral hazard risk.

On the one hand, the analysis in Kopecky and VanHoose (2006b) indicates that there may not be much of a long-run shift in banks' monitoring status in response to 
capital regulation. Nevertheless, it predicts a long-run increase in the scale of lending. Thus, a tentative implication is that the aggregate bank exposure to moral hazard risks associated with loans tends to rise. One important caveat, however, is that the KopeckyVanHoose (2006b) long-run analysis is conditioned on a given range of selected loan rates. In fact, the long-run market loan rate must tend to adjust as part of the banking system's adjustment to capital requirements. This loan-rate adjustment could induce endogenous responses in monitoring choice and equity values not fully taken into account in their simulations.

On the other hand, the Kopecky-VanHoose (2006a) long-run analysis takes into account market loan-rate adjustments and stochastic default risk, with the result that riskbased capital regulation has a greater potential to induce non-monitoring banks become monitors. Specifically, risk-based capital requirements are more likely to induce banks to monitor their loans if default risks are relatively high and if available monitoring technologies are both relatively cost-efficient and relatively effective in reducing the limits of the default-risk distribution. In the modern U.S. banking system, these conditions are more likely to be satisfied as compared with the past U.S. system or with banking systems in less developed nations.

\subsection{Directions for Future Research}

All three Kopecky-VanHoose studies utilize simulation techniques because a wide variety of analytically complicated, non-unique solutions are implied by the short- and long-run models. This analytic complexity arises in spite of strong simplifying assumptions. One common feature of the studies is the assumption that portfolio separation holds. Under this assumption, banks can always lend in the government securities market at a rate determined outside of the banking system and thus invariant to the scale of banks' operations in both the securities and loan markets. In other words, there are no cost trade-offs in determining the optimal quantity of loans and securities. 
Indeed, it is marginally costless for banksto operate as money market mutual funds. In addition, Kopecky and VanHoose (2006c) assume that all banks have identical equity, while, in contrast, Kopecky and VanHoose (2006a,b) assume that all banks have the same, fixed level of deposits. One obvious way to introduce an additional source of diversity into the banking system would be to contemplate a model that drops the portfolio separation assumption and also permits banks to choose different mixes of equity and deposits as well as different mixes of assets. Undoubtedly, however, broadening the range of permitted balance-sheet interdependencies would greatly complicate the analysis of a diverse banking system. Indeed, such an analysis might prove intractable.

Morrison and White (2005), Almazon (2002), Boot, and Marinc (2006) and Kopecky and VanHoose (2006b,c) have examined issues relating to heterogeneities within banking systems. Barth et al. (2004, 2006) have documented considerable diversity in risks, operations, and regulations across banking systems. Thus, another possible direction for future work would focus on developing a better understanding of how the effects of capital requirements might vary across countries.

\section{Conclusion}

Recent research seeking to understand how the implementation of bank capital requirements affects banks and their exposure to risks has emphasized the monitoring function of banks. This new focus is consistent with evidence suggesting that banks' screening and monitoring operations make bank loans "special.”

Most research highlighting the monitoring function of banks has followed the rest of the capital-requirements literature by assuming a representative-bank framework. In reality, of course, banks are diverse institutions. Some of these institutions choose to incur costs that enable them to monitor loans for moral hazard risks more effectively than other institutions. As a consequence of this source of diversity, banks respond differently to factors such as market interest rates or capital adequacy requirements. Their loan supply 
choices are interdependent with their decisions about whether or how much to monitor their loans for moral hazard risks. Responses of the aggregate supply of loans and the market loan rate, therefore, are linked to the underlying diversity of the banking system. Heterogeneous monitoring choices across the banking system affect market outcomes. Market outcomes, in turn, influence individual banks' decisions about loan monitoring.

Only a few recent studies, including Morrison and White (2005), Almazon (2002), Boot and Marinc (2006), and Kopecky and VanHoose (2006a,b,c) have sought to account for the effects of monitoring diversity on bank capital choices. Of these, only the Kopecky-VanHoose analyses seek to contrast the effects of capital requirements on bank behavior in both unregulated and regulated banking systems. In general, their analyses fail to provide support for the commonly espoused view that systems of bank capital regulation will generate an overall reduction in bank loan risk, either in the short run when banks cannot readily adjust equity or in the long run when equity is variable. Their work also suggests other unaddressed issues with considerable policy relevance, such as how heterogeneities in exposure of loans to moral hazard risks matter both within and across banking systems. These are issues that should be explored in future research focusing on how capital requirements affect bank loan-monitoring incentives. 


\section{REFERENCES}

Almazon, Andres. 2002. A model of competition in banking: Bank capital versus expertise. Journal of Financial Intermediation 11, 87-121.

Barth, James, Gerard Caprio Jr., and Ross Levine. 2006. Rethinking Bank Regulation. Cambridge: Cambridge University Press.

Barth, James, Gerard Caprio Jr., and Ross Levine. 2004. Bank regulation and supervision: What works best? Journal of Financial Intermediation 13, 205-248.

Besanko, David, and George Kanatas. 1996. The regulation of bank capital: Do capital standards promote bank safety? Journal of Financial Intermediation 5, 160-183.

Billett, Matthew, Mark Flannery, and Jon Garfinkel. 1995. The effect of lender identity on a borrowing firm's equity return. Journal of Finance 50, 699-718.

Boot, Arnoud, and Matej Marinc. 2006. Competition and entry in banking: Implications for Stability and Capital Regulation. Tinbergen Institute Discussion Paper TI 2006-015/2, January 22.

Campbell, Tim, Yuk-Shee Chan, and Anthony Marino. 1992. An incentive-based theory of bank regulation. Journal of Financial Intermediation 2, 255-276.

Casolaro, Luca, Dario Focarelli, and Alberto Franco Pozzolo. 2003. The pricing effect of certification on bank loans: Evidence from the syndicated credit market. Economics and Statistics Discussion Paper No. 10/03, University of Molise.

Datta, Sudip, Mai Iskandar-Datta, and Ajay Patel. 1999. Bank monitoring and the pricing of corporate debt. Journal of Financial Economics 51, 435-449.

Dahiya, Sandeep, Manju Puri, and Anthony Saunders. 2003. Bank borrowers and loan sales: New evidence on the uniqueness of bank loans. Journal of Business 76, 563-582.

Decamps, Jean-Paul, Jean-Charles Rochet, and Benoit Roger. 2004. The three pillars of Basel II: Optimizing the mix. Journal of Financial Intermediation 13, 132-155. 
Diamond, Douglas. 1996. Financial intermediation as delegated monitoring: A simple example. Federal Reserve Bank of Richmond Economic Quarterly 82/3, Summer, 51-66.

Diamond, Douglas. 1991. Monitoring and regulation: The choice between bank loans and directly placed debt. Journal of Political Economy 99, 689-721.

Diamond, Douglas. 1984. Financial intermediation and delegated monitoring. Review of Economic Studies 51, 393-414.

Diamond, Douglas, and Ragharam Rajan. 2006. Money in a theory of banking. American Economic Review 96, 30-53.

Diamond, Douglas, and Ragharam Rajan. 2001. Liquidity risk, liquidity creation, and financial fragility: A theory of banking. Journal of Political Economy 109, 287327.

Diamond, Douglas, and Raghuram Rajan. 2000. A theory of bank capital. Journal of Finance 55, 2431-2465.

Gande, Amar, Manju Puri, and Anthony Saunders. 1997. Bank underwriting of debt securities: Modern evidence. Review of Financial Studies 10, 1175-1202.

Gorton, Gary, and George Pennacchi. 1995. Banks and loan sales: Marketing nonmaketable assets. Journal of Monetary Economics 35, 389-411.

Hoshi, Takeo, Anil Kashyap, and David Scharfstein. 1991. Corporate structure, liquidity, and investment: Evidence from Japanese industrial groups. Quarterly Journal of Economics 106, 33-60.

James, Christopher. 1987. Some evidence on the uniqueness of bank loans. Journal of Financial Economics 19, 217-235.

Kopecky, Kenneth, and David VanHoose, 2006a. A stochastic model of capital regulation with a heuristic application to the U.S. banking system. Working Paper, Temple University and Baylor University. 
Kopecky, Kenneth, and David VanHoose. 2006b. Bank equity and monitoring with and without capital regulation. Working Paper, Temple University and Baylor University.

Kopecky, Kenneth, and David VanHoose. 2006c. Capital regulation, heterogeneous monitoring costs, and aggregate loan quality. Journal of Banking and Finance, 30, $1235-1255$.

Kwan, Simon. 2001. Financial modernization and banking theories. Federal Reserve Bank of San Francisco Economic Letter, No. 2001-37, December 21.

Mester, Loretta, Leonard Nakamura, and Micheline Renault. 2005. Transactions accounts and loan monitoring. Research Department, Federal Reserve Bank of Philadelphia, Working Paper No. 05-14, June.

Morrison, Alan, and Lucy White. 2005. Crises and capital requirements in banking, American Economic Review 95, 1548-1572.

Santos, João. 2001. Bank capital regulation in contemporary banking theory: A review of the literature. Financial Markets, Institutions, and Instruments 10, 41-84.

Santos, João. 1999. Bank capital and equity investment regulations. Journal of Banking and Finance 23, 1095-1120.

VanHoose, David. 2006. Bank behavior under capital regulation: What does the academic literature tell us? Networks Financial Institute Working Paper Series, 2006-WP-04. 